Jurnal Ekonomi Pembangunan

Volume 12, Nomor 1, Juni 2011, hlm.128-146

\title{
MODEL DINAMIS SISTEM KETERSEDIAAN DAGING SAPI NASIONAL
}

\author{
Harmini, Ratna Winandi Asmarantaka, dan Juniar Atmakusuma \\ Departemen Agribisnis, Fakultas Ekonomi dan Manajemen, Institut Pertanian Bogor \\ Jalan Kamper Wing 2 Lantai 5, Kampus IPB Dramaga, Bogor-Indonesia 16680, Telepon: +62-251-626520
}

Diterima 29 Desember 2010/Disetujui 2 April 2011

\begin{abstract}
The purpose of this paper is to assess whether the national program on beef self sufficiency could be achieved at 2014. A dynamic system model with Vensim computer program is applied. The model validated by Mean Absolute Percentage Error. The results shows high accuracies of the model. The assessment show that, first, the beef self sufficiency would not be achieved at 2014 if the program are treated and running as usual (Scenario I). Second, the beef self sufficiency would be achieved at 2015 if government increase the cow population by reducing the slaughter of local cows and expanding the cross breeding program through artificial insemination (Scenario II). Third, the beef self sufficiency would not be achieved at 2014 if the actual beef consumption are higher than the supply that produce through Scenario II (Scenario III). Another innovative solution for increasing local cow population is needed.
\end{abstract}

Keywords: dynamic model, beef self sufficiency, beef production, beef consumption

\begin{abstract}
Abstrak: Tulisan ini bertujuan mengkaji apakah target program swasembada daging sapi nasional pada tahun 2014 dapat dicapai. Model dinamis dengan program komputer Vensim digunakan dalam analisis. Validasi model diperiksa melalui Mean Absolute Percentage Error. Hasil validasi model menunjukkan akurasi yang tinggi. Hasil simulasi menunjukkan bahwa, pertama, program swasembada daging sapi tidak tercapai pada tahun 2014 bila program dijalankan secara business as usual (Skenario I). Kedua, swasembada daging sapi diproyeksikan dapat tercapai pada tahun 2015, apabila pemerintah menerapkan kebijakan pengurangan pemotongan sapi lokal betina produktif dan meningkatkan program kawin silang sapi lokal dengan inseminasi buatan (Skenario II). Ketiga, swasembada daging sapi tidak tercapai pada tahun 2014 apabila konsumsi daging sapi ternyata lebih tinggi dari pasokan yang dihasilkan melalui Skenario II (Skenario III). Langkah-langkah inovatif untuk meningkatkan populasi sapi sangat diperlukan.
\end{abstract}

Kata kunci: model dinamis, swasembada daging sapi, produksi daging sapi, konsumsi daging sapi

\section{PENDAHULUAN}

Kebutuhan konsumsi daging sapi penduduk Indonesia cenderung terus meningkat sejalan dengan meningkatnya jumlah penduduk Indonesia dan kesadaran masyarakat akan pentingnya protein hewani. Laju permintaan daging sapi yang meningkat ini tidak diimbangi oleh peningkatan produksi daging sapi dalam negeri. Sehingga saat ini ketersediaan daging sapi nasional masih mengalami kekurangan, yang ditutup melalui impor sekitar 35 persen dari total kebutuhan daging sapi nasional (Ditjennak, 2010a).

Salah satu kebijakan penting Kementerian Pertanian adalah swasembada daging sapi berbasis sumberdaya domestik (Ditjennak, 2010b). Program nasional untuk swasembada daging sapi tahun 2014, sebenarnya merupakan ketiga kalinya yang dicanangkan pemerintah. Melalui 
kebijakan ini ketergantungan atas impor sapi dan impor daging sapi diperkecil dengan meningkatkan potensi sapi dalam negeri. Sasarannya, pada tahun 2014 mendatang impor sapi dan daging sapi hanya 10 persen dari total kebutuhan konsumsi masyarakat.

Untuk mencapai sasaran tersebut berbagai program dilakukan oleh pemerintah, yang bertujuan untuk meningkatkan populasi sapi lokal sebagai sumber utama daging sapi. Program dimaksud diantaranya adalah: (1) pengurangan pemotongan sapi lokal betina produktif, dan (2) memperluas jangkauan program kawin silang sapi betina lokal dengan inseminasi buatan (Ditjennak, 2010c).

Menjadi penting kemudian untuk ditelaah, sejauh mana sasaran swasembada daging sapi dapat tercapai pada tahun 2014 melalui dua program yang diutarakan? Berangkat dari permasalahan tersebut penelitian ini bertujuan untuk (1) Mengidentifikasi secara menyeluruh (holistik) sistem ketersediaan daging sapi nasional, (2) Menyusun model dinamis sistem ketersediaan daging sapi nasional dan (3) Memproyeksikan ketersediaan daging sapi nasional di masa mendatang melalui simulasi model dinamis.

Metode Pengembangan Model Dinamis. Tulisan ini menggunakan pendekatan model dinamis, yang dibangun berdasarkan atas metodologi "system dynamics" yang pada awalnya dikembangkan oleh Jay W. Forrester. Model yang dibangun dengan pendekatan sistem dinamis memungkinkan semua variabel sosialekonomi dapat dimasukkan ke dalam sistem. Model dinamis merupakan suatu abstraksi dan simplifikasi dari suatu sistem yang kompleks, namun diupayakan mampu merepresentasikan sistem tersebut dengan baik. Selanjutnya, berpijak pada model dinamis yang diperoleh, dilakukan simulasi skenario kebijakan berdasarkan asumsi-asumsi yang dikembangkan secara logis (Sterman, 2000).

Dalam konteks sistem dinamis ketersediaan daging sapi nasional, yang menjadi tema sentral penelitian ini, dilakukan dalam enam tahap analisis. Pertama, memahami terlebih dahulu kompleksitas struktur hubungan sebab akibat di dalam sistem ketersediaan daging sapi nasional, yang terdiri dari sub sistem kebutuh- an daging sapi nasional (masyarakat Indonesia) dan sub sistem penyediaan (produksi) daging sapi nasional. Masing-masing sub sistem dibangun oleh faktor-faktor yang khas dan berinteraksi secara dinamis menurut waktu dan kondisi. Kemampuan pemahaman atas sistem yang ditelaah akan menentukan model dinamis yang dihasilkan. Kedua, mengkonstruksikan struktur hubungan sebab akibat di dalam sistem ketersediaan daging sapi nasional ke dalam bentuk diagram causal loop. Ketiga, menentukan asumsi dasar model dinamis. Model dinamis sistem ketersediaan daging sapi nasional, yang merupakan output dari penelitian ini, dibangun berlandaskan atas beberapa asumsi dasar. Asumsi ditentukan berdasarkan kajian teoritik dengan berlandaskan pada data sekunder yang sebagian besar bersumber dari Direktorat Jendral Peternakan Kementerian Pertanian Republik Indonesia. Asumsi yang ditetapkan akan menentukan hasil proyeksi yang dihasilkan model, dengan kata lain asumsi yang berbeda akan memberikan hasil proyeksi ketersediaan daging sapi nasional yang berbeda. Keempat, memformulasikan model dinamis ketersediaan daging sapi nasional berlandaskan atas diagram causal loop dan asumsi dasar model dinamis. Kelima, validasi model dinamis. Keenam, tahap terakhir, simulasi terhadap beberapa skenario kebijakan program swasembada daging sapi nasional.

Program komputer Dynamo, Powersim, Stella/iThink, atau Vensim dapat digunakan untuk memformulasikan model dinamis. Pada tulisan ini penulis menggunakan program Vensim (Ventana Systems, 2007). Program Vensim dipilih karena pertimbangan telah mencukupi kebutuhan model yang akan dibangun. Formulasi model dinamis dinyatakan dalam bahasa grafis dan matematis. Penyajian model dinamis dalam bahasa grafis secara sederhana diuraikan melalui contoh pada Gambar 1.

Model dinamis dalam bahasa grafis dinyatakan dalam lima simbol (lihat Gambar 1), yakni: (1) Stock (gambar kotak) menyatakan akumulasi dari suatu aliran di dalam sistem (contohnya populasi penduduk), (2) Rate menyatakan tingkat penambahan (inflow) (contohnya jumlah kelahiran) atau pengurangan (outflow) (contohnya jumlah kematian) dari Stock 


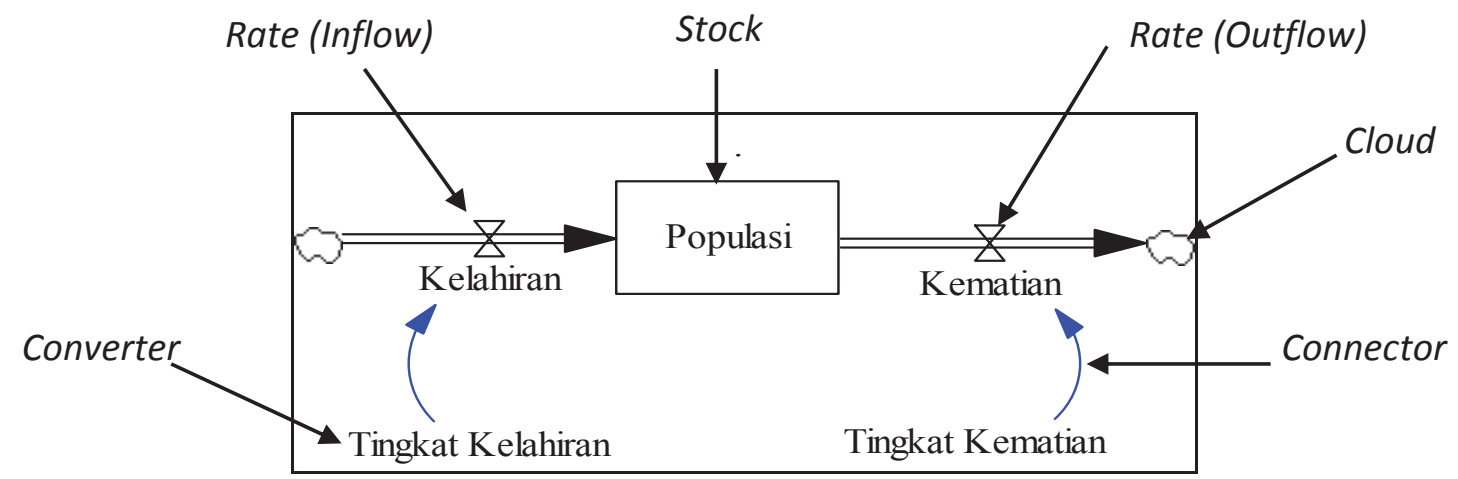

Sumber: Sterman (2000).

Gambar 1. Bahasa Grafis Sistem Dinamis

setiap periode yang menunjukkan aktivitas dari sistem, (3) Converters menyatakan input yang bisa dinyatakan dalam angka atau formula atau grafik (besarannya ditentukan oleh pembangun model), (4) Connectors (gambar tanda panah) menunjukkan aliran informasi (hubungan) di dalam sistem (sumber panah menunjukkan variabel yang mempengaruhi dan di ujung tanda panah adalah variabel yang dipengaruhi), (5) Cloud menyatakan batasan sistem.

Stock adalah akumulasi dari suatu aliran. Aliran bersih ke dalam Stock adalah tingkat perubahan pada Stock. Secara matematis besarnya Stock pada waktu $\mathrm{t}$ dinyatakan ke dalam ke persamaan integral berikut ini.

$\operatorname{Stock}(t)=\int_{t_{o}}^{t}[\operatorname{Inflow}(s)-\operatorname{Outflon}(s)] d s+\operatorname{Stock}\left(t_{o}\right)$

dimana Inflow(s) adalah besarnya Inflow (penambahan Stock) dan Outflow(s) adalah besarnya pengurangan Stock selama periode s di antara waktu awal $\left(t_{0}\right)$ hingga saat ini $(t)$ (Sterman, 2000).

Data yang digunakan pada penelitian ini terutama berlandaskan pada data sekunder, yang sebagian besar bersumber dari Direktorat Jendral Peternakan Kementan RI. Untuk mempertajam analisis dilakukan wawancara mendalam dengan pakar peternakan Indonesia (Prof. Riset. Dr. Sjamsul Bahri, MS) dan dari telaah berbagai referensi yang relevan dan mendukung tulisan ini.

\section{HASIL DAN PEMBAHASAN}

\section{Sistem Ketersediaan Daging Sapi Nasional}

Untuk mencapai sasaran program swasembada daging sapi nasional pada tahun 2014, berbagai kebijakan dan program telah dicanangkan oleh pemerintah. Program-program tersebut secara umum bertujuan untuk menambah populasi sapi dan produktivitas sapi, dengan mengembangkan potensi persapian Indonesia (nasional) yang sekarang ada. Kebijakan penambahan populasi dan produktivitas sapi bertujuan untuk menambah kemampuan penyediaan (produksi) daging sapi nasional.

Jumlah daging sapi yang harus disediakan, ditentukan oleh kebutuhan konsumsi daging sapi penduduk secara nasional. Sementara kebutuhan konsumsi daging sapi nasional ditentukan oleh jumlah penduduk dan konsumsi daging sapi per kapita masyarakat Indonesia. Sejalan dengan pertumbuhan penduduk dan semakin meningkatnya kesadaran masyarakat akan pentingnya protein hewani, maka kebutuhan daging sapi nasional juga akan cenderung semakin meningkat (Dwiyanto, 2008).

Produksi daging sapi nasional dipengaruhi oleh populasi sapi dan kualitas sapi. Kualitas sapi yang baik akan tercermin dari berat per 
ekor dan persentase karkas yang semakin tinggi. Upaya peningkatan kualitas sapi identik dengan peningkatan produktifitas daging sapi. Semakin besar populasi dan semakin tinggi produktivitas daging sapi maka kemampuan penyediaan daging sapi nasional akan cenderung semakin tinggi. Tingkat keberhasilan pemerintah dalam program peningkatan populasi dan kualitas sapi pada akhirnya akan menentukan tingkat keberhasilkan program nasional swasembada daging sapi. Populasi sapi tersebar di berbagai wilayah Indonesia dan di berbagai peternakan sapi dengan jumlah yang variatif (Ditjennak, 2010c).

Peternakan sapi Indonesia umumnya merupakan peternakan rakyat, sebagian kecil berupa perusahaan swasta dan peternakan pemerintah. Pada peternakan rakyat seringkali terjadi kasus, dimana sapi betina dewasa telah dijual atau dipotong sebelum masa produktifnya habis, karena berbagai alasan kebutuhan dana cash (untuk menutupi biaya sekolah anak, biaya kesehatan, biaya awal musim tanam dan kebutuhan lainnya). Dalam jangka panjang, semakin banyak sapi lokal betina produktif yang dipotong sebelum masa produktifnya produktifnya habis sapi betina siap ke pemotongan. Umur sapi jantan pada saat pemotongan bervariasi, ada sebagian yang dipotong umur 3 tahun, sebagian lagi dipotong pada saat umur 4 tahun. Perpanjangan umur potong sapi jantan dari 3 tahun ke 4 tahun dimaksudkan untuk meningkatkan berat per ekor sapi pada saat dipotong. Di samping itu, di peternakan rakyat ada sekitar 10 persen sapi jantan lokal digunakan sebagai pejantan dan dipotong setelah umur 9 tahun (Bahri, 2011, Pers. Comm). Dengan demikian, dari total populasi sapi yang ada dapat dikelompokkan menurut umur dan jenis kelamin, yakni: (1) populasi sapi betina muda (0-2 tahun), (2) populasi sapi betina dewasa (>2-9 tahun), (3) populasi sapi jantan (09 tahun).

Penambahan (inflow) populasi sapi per tahun ditentukan oleh calf crop. Calf crop adalah persentase sapi betina dewasa yang melahirkan pada tahun berjalan dari total populasi sapi betina dewasa pada tahun tersebut. Pengurangan (outflow) populasi sapi ditentukan oleh tingkat kematian sapi (mortalitas) dan jumlah pemotongan sapi (Ensminger, 1990). Pada tahun 2008 tingkat mortalitas anak sapi di pe- 
sapi masyarakat Indonesia, dapat dipenuhi dari produksi daging sapi dalam negeri. Kemandirian dalam hal daging sapi diharapkan dapat dicapai secara bertahap. Apabila kebutuhan daging sapi nasional lebih besar dari produksi daging sapi nasional, maka kekurangannya akan dipenuhi dari impor daging sapi dan atau impor dalam bentuk sapi bakalan. Target pemerintah pada tahun 2014 impor daging sapi (sapi bakalan) hanya 10 persen dari total kebutuhan konsumsi masyarakat (Ditjennak, 2010c).

\section{Diagram Causal Loop Sistem Ketersediaan Daging Sapi Nasional}

Berdasarkan uraian sebelumnya dapat disimpulkan bahwa ketersediaan daging sapi nasional ditentukan produksi dan kebutuhan konsumsi daging sapi nasional. Produksi daging sapi nasional terdiri atas 2 sub sistem. Pertama, sub sistem produksi daging sapi yang berasal dari peternakan sapi lokal. Kedua, sub sistem produksi daging sapi yang berasal dari peternakan sapi perah.

Produksi daging sapi pada kedua sub sistem tersebut dipengaruhi oleh populasi sapi, lebih khusus lagi dipengaruhi oleh jumlah sapi betina dewasa afkir, jumlah sapi jantan siap potong, fraksi daging dan berat per ekor sapi. Khusus untuk peternakan sapi lokal, produksi daging sapi juga ditentukan oleh jumlah sapi betina dewasa yang dipotong sebelum masa

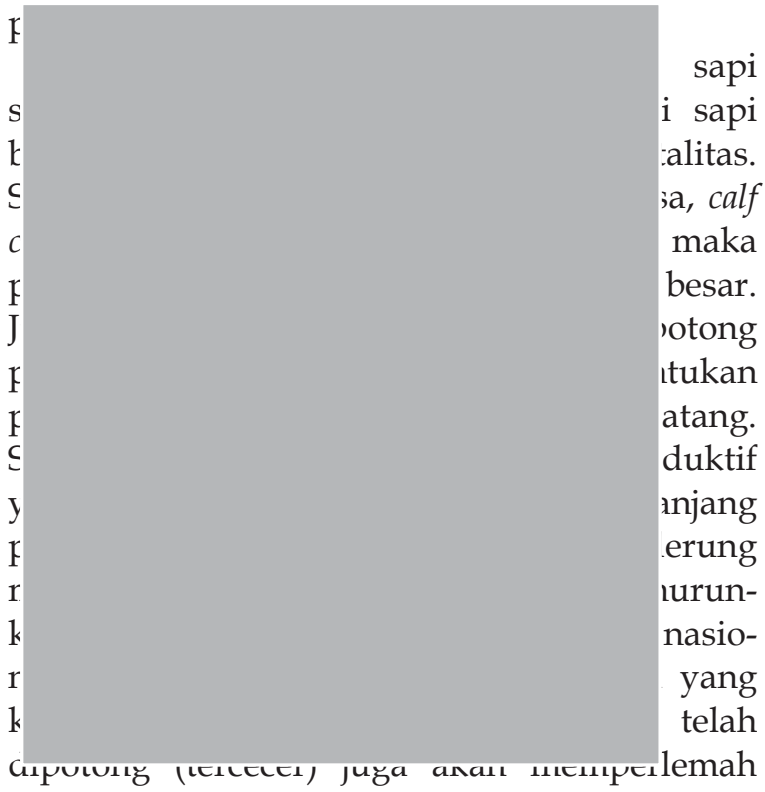

kemampuan penyediaan daging sapi bagi masyarakat Indonesia.

Kebutuhan konsumsi daging sapi nasional ditentukan oleh jumlah penduduk dan konsumsi daging sapi per kapita masyarakat Indonesia. Semakin besar jumlah penduduk dan konsumsi per kapita maka kebutuhan konsumsi daging sapi nasional akan meningkat.

Ketersediaan daging sapi nasional merupakan perbedaan antara total produksi dan total kebutuhan konsumsi daging sapi nasional. Kekurangan dari total kebutuhan konsumsi daging sapi masyarakat akan dipenuhi dari impor dalam bentuk daging atau sapi bakalan.

Hubungan kausal di antara variabel di dalam sistem ketersediaan daging sapi nasional yang diuraikan secara naratif tersebut, akan tampak lebih jelas apabila dinyatakan dalam bentuk visual (diagram). Hubungan kausal dalam bentuk diagram causal loop dinyatakan ke dalam lima simbol, yakni: (1) tanda panah menunjukkan arah hubungan kausal, (2) tanda positif (di ujung tanda panah) menunjukkan jika variabel penyebab meningkat maka variabel effect akan cenderung meningkat, (3) tanda negatif menunjukkan arah hubungan sebaliknya dari tanda positif, (4) notasi $R$ (Reinforcing) menunjukkan adanya pertumbuhan dan (5) notasi $B$ (balancing) menunjukkan adanya penurunan dalam jangka panjang di dalam loop tersebut. Hasil konstruksi hubungan kausal sistem ketersediaan daging sapi nasional ke dalam bentuk diagram causal loop disajikan pada Gambar 2.

\section{Asumsi Dasar Model Dinamis Sistem Ketersediaan Daging Sapi Nasional}

Model dinamis sistem ketersediaan daging sapi nasional dibangun berlandaskan atas beberapa asumsi dasar berikut:

(1) Data dasar yang digunakan untuk awal simulasi adalah data tahun 2008, dengan pertimbangan data tersebut adalah data terakhir yang secara resmi sudah dipublikasikan.

(2) Angka rata-rata pertumbuhan penduduk Indonesia diasumsikan sebesar 1,264 persen per tahun. Angka tersebut ditentukan dari data jumlah penduduk Indonesia tahun 2000 sebesar 206.264.595 jiwa (http://bps.go.id/) dan pada tahun 2010 jumlah penduduk Indonesia sebesar 237.560.000 jiwa (Kompas, 1 Maret 2011). De- 


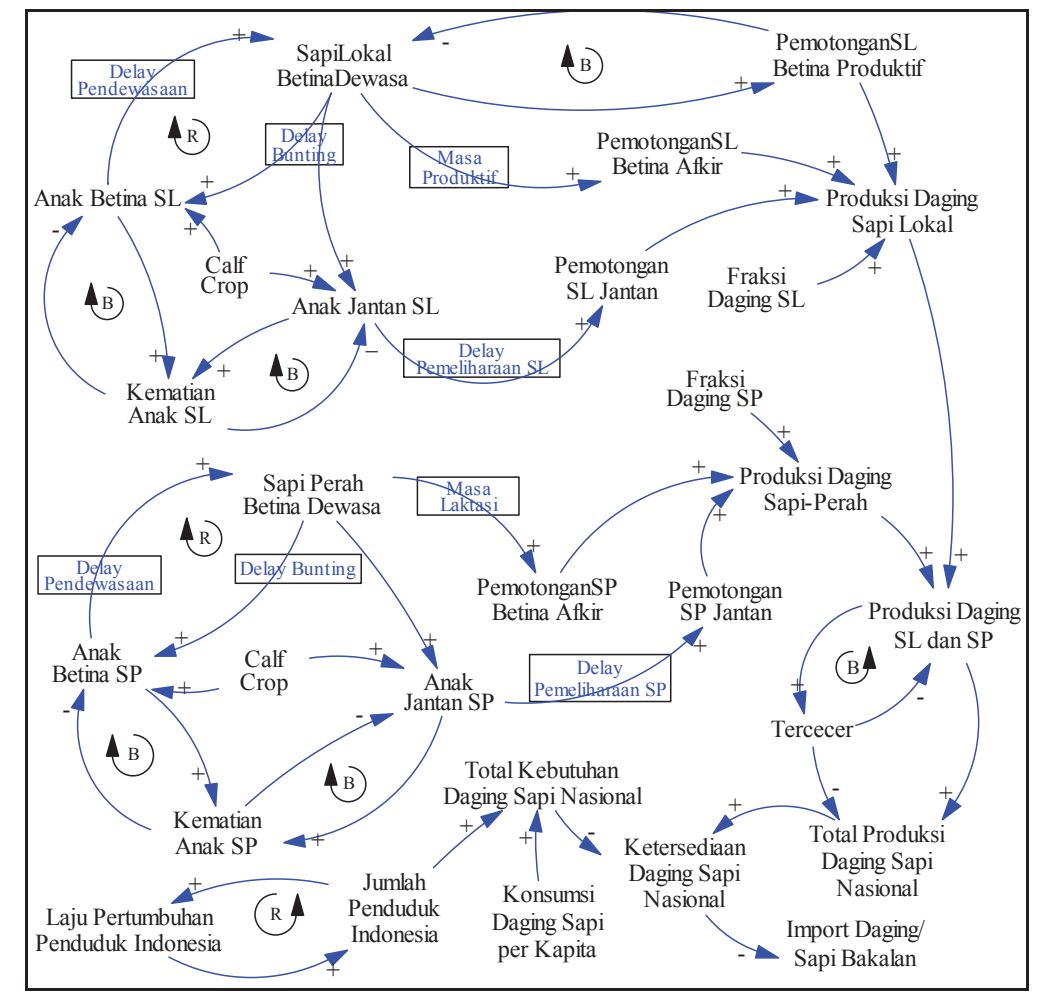

Gambar 2. Diagram Causal Loop Sistem Ketersediaan Daging Sapi Nasional

ngan intrapolasi jumlah penduduk Indonesia tahun 2008 dapat ditentukan sebesar:

227.128.198 jiwa.

(3) Konsumsi daging sapi masyarakat Indonesia per kapita per tahun diasumsikan seperti terdapat pada Tabel 1.

(4) Asumsi dasar untuk sub sistem produksi daging sapi dari peternakan sapi lokal.

(a) Sapi lokal betina siap kawin setelah umur 2 tahun, dengan Calf crop sebesar 55 persen, sex rasio kelahiran anak jantan dan betina adalah 1 dibanding 1, tingkat kematian anak sebesar 10 persen dengan masa produktif 7 tahun, selanjutnya diafkir dengan berat rata-rata $325 \mathrm{~kg}$ per

Tabel 1. Konsumsi dan Proyeksi Konsumsi Daging Sapi Nasional Per Tahun.

\begin{tabular}{cc}
\hline Tahun & $\begin{array}{c}\text { Rata-rata Konsumsi Daging Sapi Penduduk } \\
\text { Indonesia (Kg/Kapita/Tahun) }\end{array}$ \\
\hline 2008 & 1,48 \\
2009 & 1,52 \\
2010 & 1,55 \\
2011 & 1,59 \\
2012 & 1,63 \\
2013 & 1,67 \\
2014 & 1,73 \\
2015 & 1,77 \\
2016 & 1,81 \\
2017 & 1,86 \\
\hline Keterangan: Angka konsumsi tahun 2008-2010 diolah dari \\
Ditjennak (2010b) dan pada tahun-tahun selanjutnya diasumsikan \\
konsumsi meningkat konstan sebesar 2,5\% per tahun.
\end{tabular}


Tabel 2. Sebaran Populasi Sapi Lokal Indonesia menurut Jenis Kelamin dan Umur Sapi Tahun 2008.

\begin{tabular}{lrr}
\hline Sapi Lokal Indonesia Menurut Jenis & $\begin{array}{r}\text { Persentase } \\
\text { Kelamin dan Umur }\end{array}$ & $\begin{array}{r}\text { Populasi Sapi Lokal } \\
\text { Indonesia Tahun 2008 (Ekor) }\end{array}$ \\
\hline 1. Betina Muda (0-2 Tahun) & 24,93 & 2.799 .372 \\
2. Betina Dewasa (>2-9 Tahun) & 42,03 & 4.719 .518 \\
3. Jantan (0-4 Tahun) & 33,04 & 3.710 .037 \\
\hline Total Populasi Sapi Lokal Indonesia Tahun & & \\
2008 & 100 & 11.228 .927 \\
\hline
\end{tabular}

Keterangan: Diolah dari Ditjennak (2009)

ekor (Ensminger, 1990) dan (Bahri, 2011, Pers. Comm).

(b) Pemotongan sapi lokal jantan, diasumsikan 80 persen dipotong pada umur 3 tahun dengan rata-rata berat $225 \mathrm{Kg}$ /ekor, dan 10 persen dipotong pada umur 4 tahun dengan berat 325 $\mathrm{Kg} /$ ekor, serta 10 persen dipotong setelah umur 9 tahun dengan berat $350 \mathrm{Kg} /$ ekor (Bahri, 2011, Pers. Comm).

(c) Sebaran populasi sapi lokal Indonesia, menurut jenis kelamin dan umur sapi pada tahun 2008, ditentukan berdasarkan atas: (1) data total populasi sapi lokal Indonesia tahun 2008, yakni sebesar 11.228.927 ekor, dan (2) data perbandingan persentase jumlah sapi betina muda, betina dewasa, dan jantan. Hasil perhitungan Sebaran populasi sapi lokal Indonesia, menurut jenis kelamin dan umur sapi pada tahun 2008, disajikan pada Tabel 2.

(5) Asumsi dasar untuk subsistem produksi daging sapi yang berasal dari peternakan sapi perah:

(a) Sapi perah betina siap kawin setelah umur 2 tahun, dengan Calf crop 55 persen, sex rasio kelahiran anak jantan dan betina 1 dibanding 1 , tingkat kematian anak sebesar 10 persen, dengan masa produktif 6 tahun, selanjutnya diafkir dengan berat rata-rata $350 \mathrm{Kg}$ per ekor (Ensminger, 1990) dan (Bahri, 2011, Pers. Comm).

(b) Pemotongan sapi perah jantan, diasumsikan 90 persen dipotong pada umur 3 tahun dengan rata-rata berat sapi $250 \mathrm{~kg} /$ ekor, dan 10 persen dipotong pada umur 4 tahun dengan berat 350 kg/ekor (Bahri, 2011, Pers. Comm).

(c) Sebaran populasi sapi perah Indonesia menurut jenis kelamin dan umur sapi pada tahun 2008 ditentukan berdasarkan atas: (1) data total populasi sapi perah Indonesia tahun 2008, yakni sebesar 457577 ekor, dan (2) data perbandingan persentase jumlah sapi betina muda, betina dewasa, dan jantan. Hasil perhitungan, sebaran populasi sapi perah Indonesia menurut jenis kelamin dan umur sapi pada tahun 2008, disajikan pada Tabel 3.

(6) Kandungan daging per ekor sapi diasumsikan sebesar 41,25 persen. Angka tersebut diperoleh dari, karkas per ekor sapi rata-rata sebesar 55 persen dengan kandungan daging sebesar 75 persen dari karkas, sehingga kan-

Tabel 3. Sebaran Populasi Sapi Perah Indonesia menurut Jenis Kelamin dan Umur Sapi Tahun 2008.

\begin{tabular}{lcc}
\hline $\begin{array}{l}\text { Sapi Perah Indonesia } \\
\text { Menurut Jenis Kelamin dan Umur }\end{array}$ & $\begin{array}{c}\text { Persentase } \\
\mathbf{( \% )}\end{array}$ & $\begin{array}{c}\text { Populasi Sapi Perah Indonesia } \\
\text { Tahun 2008 (Ekor) }\end{array}$ \\
\hline Betina Muda (0-2 Tahun) & 27,34 & 125.102 \\
Betina Dewasa (>2-8 Tahun) & 61,00 & 279.122 \\
Jantan (0-4 Tahun) & 11,66 & 53.353 \\
\hline Total Populasi Sapi Perah Indonesia & & 457.577 \\
Tahun 2008 & 100 & \\
\hline
\end{tabular}

Keterangan: Diolah dari Ditjennak (2009). 
dungan daging per ekor sapi $=55 \% * 75 \%=$ 41.25\% (Bahri, 2011, Pers. Comm).

(7) Rata-rata daging sapi yang tercecer adalah 5,95 persen dari total produksi daging sapi nasional (diolah dari Ditjennak, 2009).

\section{Model Dinamis Sistem Ketersediaan Daging Sapi Nasional}

Berdasarkan atas diagram causal loop (Gambar
2) dan asumsi dasar model yang telah diuraikan sebelumnya, maka disusunlah model dinamis sistem ketersediaan daging sapi nasional dengan menggunakan program Vensim. Hasil akhir formulasi model dinamis sistem ketersediaan daging sapi nasional dalam bahasa grafis tersaji pada Gambar 3, sedangkan dalam bahasa matematis tersaji pada Lampiran.

Formulasi model dinamis menyatakan hu-

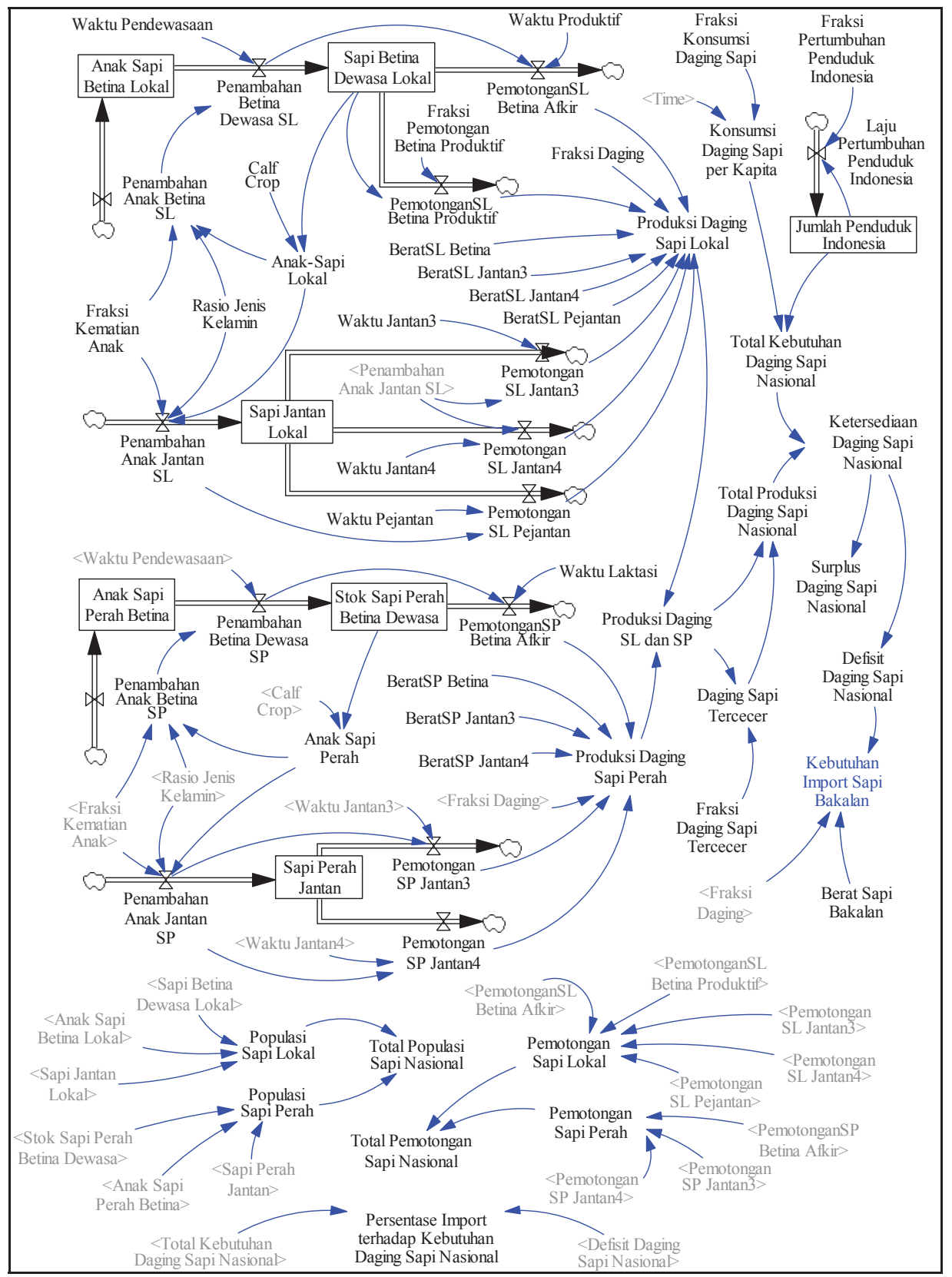

Gambar 3. Model Dinamis Sistem Ketersediaan Daging Sapi Nasional 
Tabel 4. Nilai MAPE Berdasarkan Total Produksi Daging Sapi Nasional dan Total Konsumsi Daging Sapi Nasional.

\begin{tabular}{llccc}
\hline \multirow{2}{*}{ Variabel Kunci } & \multicolumn{2}{c}{ Tahun } & MAPE \\
\cline { 3 - 4 } & & $\mathbf{2 0 0 8}$ & $\mathbf{2 0 0 9}$ & $\mathbf{( \% )}$ \\
\hline Total Produksi Daging Sapi Nasional (ribu ton) & Aktual & 233,60 & 250,80 & 5,80 \\
Total Kebutuhan Konsumsi Daging Sapi Nasional & Model & 226,46 & 229,55 & \\
(ribu ton) & Aktual & 313,30 & 325,90 & 7,28 \\
\hline
\end{tabular}

Keterangan: Nilai aktual dikutip dari Ditjennak (2010b).

bungan di antara variabel di dalam sistem. Formulasi model sistem ketersediaan daging sapi nasional (Gambar 3) dinyatakan ke dalam dua sub sistem. Pertama, sub sistem produksi daging sapi nasional. Kedua, sub sistem kebutuhan konsumsi daging sapi nasional.

Sub sistem produksi daging sapi nasional menyatakan bahwa produksi daging sapi nasional berasal dari perternakan sapi lokal dan

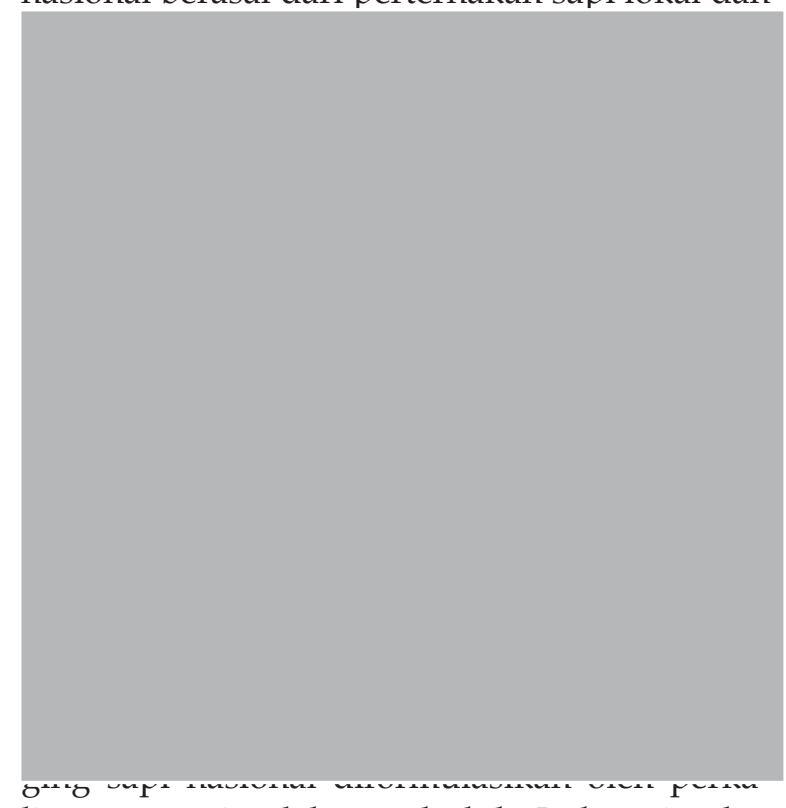

lian antara jumlah penduduk Indonesia dan konsumsi daging sapi per kapita per tahun. Sementara itu jumlah penduduk Indonesia bertambah setiap tahun dengan pertumbuhan ratarata sekitar 1,264 persen per tahun.

\section{Validasi Model Dinamis Sistem Ketersedia- an Daging Sapi Nasional}

Validitas model dinamis pada penelitian ini dinilai dari logika model. Model dinamis, walaupun dalam bentuk abstraksi dan simpli- fikasi dari realita, namun tetap diupayakan agar dapat merepresentasikan kondisi aktual dengan baik dan logis. Di samping itu, juga diuji kesahihannya dengan kriteria berikut,

$$
\sum_{t=1}^{n} \frac{\left(\left|\frac{\epsilon_{t}}{Y_{t}} * 100 \%\right|\right)}{n}
$$

dimana $Y_{t}$ adalah nilai aktual variabel $Y$ pada periode $t, \epsilon_{t}$ adalah perbedaan antara nilai aktual dengan hasil prediksi model atau kesalahan ramalan, MAPE adalah Mean Absolute Percentage Error (rata-rata persentase absolut kesalahan terhadap aktual).

Semakin kecil nilai MAPE, semakin tinggi validitas model yang diuji karena secara umum nilai aktual variabel yang dievaluasi $(\mathrm{Y})$ semakin dekat dengan nilai $\mathrm{Y}$ yang diprediksi oleh model dinamis. Validitas model pada tulisan ini dinilai dari variabel kunci total produksi daging sapi nasional dan total kebutuhan konsumsi daging sapi nasional. Berdasarkan data aktual tahun 2008-2009 dan hasil simulasi model dinamis, diperoleh nilai MAPE sebagaimana disajikan pada Tabel 4.

Berdasarkan atas nilai MAPE dari kedua variabel kunci tersebut dapat disimpulkan bahwa model dinamis yang tersusun telah memiliki akurasi yang tinggi, dengan rata-rata MAPE sebesar 5,8 persen untuk variabel total produksi daging sapi nasional, dan 7,28 persen untuk variabel total kebutuhan konsumsi daging sapi nasional.

\section{Simulasi Model Dinamis Sistem Ketersedia- an Daging Sapi Nasional}

Pada penelitian ini, simulasi model dinamis hanya akan dilakukan atas tiga skenario kebi- 
Tabel 5. Target dan Implementasi Program Pengurangan Pemotongan Sapi Lokal Betina Produktif

\begin{tabular}{llllllll}
\hline $\begin{array}{l}\text { Target Program Pengurangan } \\
\text { Pemotongan Sapi Lokal Betina } \\
\text { Produktif }\end{array}$ & $\mathbf{5}$ & \multicolumn{5}{c}{ Tahun Implementasi } \\
\cline { 2 - 7 } & $\mathbf{2 0 1 1}$ & $\mathbf{2 0 1 2}$ & $\mathbf{2 0 1 3}$ & $\mathbf{2 0 1 4}$ & $\mathbf{2 0 1 5}$ & $\mathbf{2 0 1 6}$ & $\mathbf{2 0 1 7}$ \\
\hline $\begin{array}{l}\text { Jumlah Pemotongan Sapi Lokal Betina } \\
\text { Produktif (ribu ekor) }\end{array}$ & 175 & 50 & 25 & 10 & 10 & 10 & 10 \\
\hline
\end{tabular}

Keterangan: Asumsi target tahun 2011-2014 (Bahri, 2011, Pers. Comm). Pada penelitian ini disimulasikan target program tersebut dapat dicapai tepat waktu.

jakan. Berdasarkan atas hasil simulasi model dinamis yang dilakukan, selanjutnya dapat dibandingkan bagaimana capaian sasaran program swasembada daging sapi nasional pada tahun 2014 mendatang.

(1) Skenario Simulasi Model Dinamis. Tiga skenario kebijakan swasembada daging sapi nasional yang disimulasikan dalam penelitian ini, yakni:

Skenario I. Apabila kondisi persapian Indonesia pada Tahun 2008 (sebagaimana diuraikan pada asumsi dasar model dinamis) berlanjut hingga Tahun 2017. Skenario I ini disebut pula sebagai bussiness as usual scenario.

Skenario II. Apabila kebijakan mengurangi pemotongan sapi lokal betina produktif dan meningkatkan jangkauan program kawin silang sapi lokal dengan inseminasi buatan berhasil dilaksanakan pemerintah.

Skenario II ini mengandung dua program. (a) Program pertama, mengurangi pemotongan sapi lokal betina produktif secara bertahap.
Jumlah pemotongan sapi lokal betina produktif pada tahun 2010 mencapai sekitar 200.000 ekor (diolah dari Ditjennak, 2010c) dan ditargetkan pada tahun 2014 dan seterusnya jumlah pemotongan sapi lokal betina produktif hanya tinggala 10.000 ekor saja. Target dan implementai program tersebut diasumsikan berlangsung seperti pada Tabel 5 .

(b) Program kedua, meningkatkan secara bertahap program kawin silang sapi lokal dengan inseminasi buatan (IB) yang pada akhirnya akan meningkatkan berat per ekor sapi dan calf crop sapi lokal. Program IB ditargetkan dapat menjangkau 90 persen sapi lokal betina produktif. Adapun target dan implementasi program ini diasumsikan berlangsung seperti pada Tabel 6.

Skenario III. Apabila terjadi peningkatkan konsumsi daging sapi per kapita masyarakat Indonesia dan sekaligus program pada Skenario II dapat berjalan sesuai dengan target dan tepat waktu. Skenario III ini disimulasikan ketika

Tabel 6. Target dan Implementasi Program Kawin Silang Sapi Lokal dengan IB.

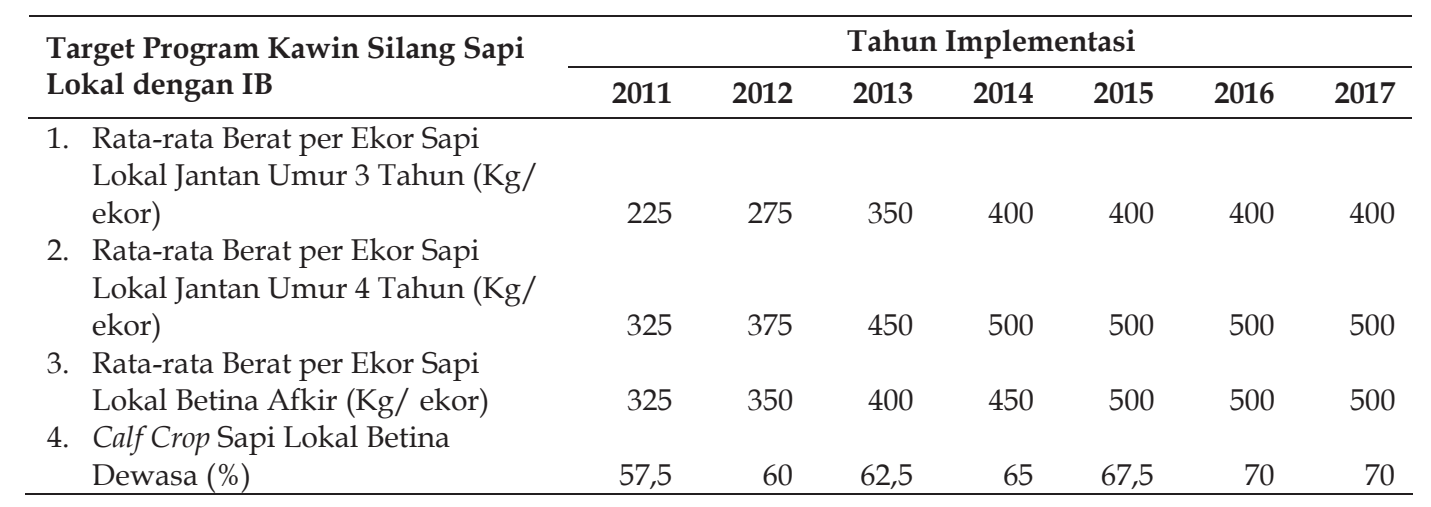

Keterangan: Asumsi target tahun 2011-2014 (Bahri, 2011, Pers. Comm). Pada penelitian ini disimulasikan target program dapat dicapai tepat waktu. 
Tabel 7. Proyeksi Rata-Rata Konsumsi Daging Sapi Penduduk Indonesia per Kapita per Tahun

\begin{tabular}{lccccccc}
\hline Tahun & 2011 & 2012 & 2013 & 2014 & 2015 & 2016 & 2017 \\
\hline $\begin{array}{l}\text { Rata-rata Konsumsi Daging Sapi } \\
\begin{array}{l}\text { Penduduk Indonesia } \\
\text { (Kg/Kapita/Tahun) }\end{array}\end{array}$ & 1,75 & 1,9 & 2,05 & 2,2 & 2,35 & 2,5 & 2,65 \\
\hline
\end{tabular}

Keterangan: Rata-rata konsumsi daging sapi penduduk Indonesia tahun 2011 sekitar 1,75 kg/kapita (BPS, 2010) dan pada tahun-tahun selanjutnya diasumsikan konsumsi meningkat konstan sebesar 1,5 ons/kapita/tahun.

target dan implementasi program pengurangan pemotongan sapi lokal betina produktif dapat dicapai dan tepat waktu (Tabel 5), serta target dan implementasi program kawin silang sapi lokal dengan IB juga dapat dicapai dan tepat waktu (Tabel 6), namun pada saat yang sama terjadi kenaikan kebutuhan konsumsi daging sapi masyarakat Indonesia, dengan rata-rata konsumsi per kapita diasumsikan akan berlangsung seperti pada Tabel 7 .

\section{Hasil Simulasi Model Dinamis Berdasarkan Skenario I}

Berdasarkan simulasi model dinamis sistem ketersediaan daging sapi nasional atas Skenario I (bussiness as usual scenario) berikut akan diuraikan hasil proyeksinya dalam dua hal: (a) proyeksi ketersediaan daging sapi nasional di masa mendatang (Tabel 8), serta (b) proyeksi populasi sapi dan total pemotongan sapi nasional (Tabel 9).

Pada Tabel 8 tampak bahwa apabila kondisi persapian Indonesia tahun 2008 berlanjut (bussiness as usual scenario), maka pada tahun 2014 Indonesia masih harus mengimpor daging sapi sebesar 35,95 persen dari total kebutuhan konsumsi daging sapi nasional. Ini berarti sasaran pemerintah bahwa impor sapi atau daging sapi pada tahun 2014 sebesar 10 persen dari total konsumsi daging sapi nasional belum dapat dicapai. Memasuki tahun 2015 diproyeksikan persentase impor daging sapi Indonesia terjadi sedikit penurunan. Namun pada tahun berikutnya (tahun 2016) persentase impor daging sapi terhadap kebutuhan daging sapi nasional akan mengalami peningkatan kembali $(21,07$ persen pada tahun 2017). Peningkatan persen-

Tabel 8. Proyeksi Ketersediaan Daging Sapi Nasional Berdasarkan atas Skenario I

\begin{tabular}{ccccc}
\hline Tahun & $\begin{array}{l}\text { Total Produksi } \\
\text { Daging Sapi } \\
\text { Nasional }\end{array}$ & $\begin{array}{l}\text { Total Kebutuhan } \\
\text { Daging Sapi } \\
\text { Nasional }\end{array}$ & $\begin{array}{l}\text { Ketersediaan } \\
\text { Daging Sapi } \\
\text { Nasional }\end{array}$ & $\begin{array}{l}\text { Persentase Impor } \\
\text { Daging Sapi terha- } \\
\text { dap Kebutuhan } \\
\text { Daging Sapi } \\
\text { Nasional }\end{array}$ \\
\cline { 2 - 5 } & (Ribu Ton) & (Ribu Ton) & (Ribu Ton) & (\%) \\
\hline 2008 & 226,46 & 336,15 & $-109,68$ & 32,63 \\
2009 & 229,55 & 349,60 & $-120,05$ & 34,34 \\
2010 & 232,48 & 361,00 & $-128,52$ & 35,60 \\
2011 & 233,49 & 375,00 & $-141,51$ & 37,74 \\
2012 & 248,11 & 389,29 & $-141,18$ & 36,27 \\
2013 & 260,73 & 403,89 & $-143,16$ & 35,45 \\
2014 & 271,37 & 423,69 & $-152,32$ & 35,95 \\
2015 & 372,89 & 438,96 & $-66,07$ & 15,05 \\
2016 & 381,91 & 454,56 & $-72,65$ & 15,98 \\
2017 & 373,36 & 473,02 & $-99,66$ & 21,07 \\
\hline
\end{tabular}

Keterangan: Hasil simulasi model dinamis atas Skenario I 
tase impor daging sapi ini akan terus berlanjut di masa mendatang apabila tidak ada program inovatif yang bertujuan menambah populasi sapi lokal sebagai sumber utama daging sapi nasional.

Sejalan dengan proyeksi produksi daging sapi nasional (Tabel 8), tampak apabila kondisi persapian Indonesia pada Tahun 2008 berlanjut (bussiness as usual scenario), maka diproyeksikan dalam jangka panjang pertumbuhan populasi sapi nasional akan cenderung semakin kecil (2,63 persen pada tahun 2017) (lihat Tabel 9). Populasi sapi nasional terutama berasal sapi lokal Indonesia yang umumnya dikuasai oleh rakyat. Kebutuhan dana cash pengusahatani sapi rakyat, menyebabkan petani terpaksa menjual atau memotong sapi betina produktif yang dimilikinya sebelum masa produktifnya habis. Dalam jangka panjang pemotongan sapi lokal betina produktif dalam jumlah yang tinggi akan memperkecil pertumbuhan populasi sapi lokal, dan selanjutnya akan menyebabkan semakin lemahnya kemampuan penyediaan daging sapi nasional.

Dari hasil simulasi skenario I (bussiness as usual scenario) dapat disimpulkan bahwa dalam jangka panjang diproyeksikan persentase impor daging sapi terhadap kebutuhan daging sapi nasional akan cenderung meningkat (Tabel 8) dan pertumbuhan populasi sapi nasional akan cenderung semakin kecil (Tabel 9). Hal ini menunjukkan bahwa agar program swasembada daging sapi nasional terwujud, maka intervensi pemerintah dalam bentuk program pengendalian pemotongan sapi lokal betina produktif dan implementasi program kawin silang melalui IB, merupakan program yang mutlak diperlukan. Program-program inovatif untuk membantu pengusahatani sapi rakyat harus terus diupayakan agar pemotongan sapi lokal betina produktif dapat ditahan.

\section{Hasil Simulasi Model Dinamis Berdasarkan Skenario II}

Dua program pemerintah yang penting dalam upaya swasembada daging sapi tahun 2014 adalah (1) pengurangan jumlah pemotongan sapi lokal betina produktif di tingkat peternakan rakyat yang bertujuan untuk meningkatkan pertumbuhan populasi sapi, (2) memperluas jangkauan kawin silang sapi lokal dengan IB yang bertujuan untuk meningkatkan kualitas sapi, yang tercermin dari peningkatan berat badan akhir, persentase karkas dan persentase daging. Apabila target kedua program tersebut dapat dicapai dan diimplementasikan tepat waktu (Tabel 5 dan Tabel 6) (Simulasi II), maka berikut ini akan diuraikan hasil simulasi model dinamis dalam dua hal, yakni: (1) proyeksi ketersediaan daging sapi nasional di masa mendatang (Tabel 10), (2) proyeksi populasi sapi dan total pemotongan sapi nasional (Tabel 11).

Pada Tabel 10 tampak bahwa apabila target dan implementasi program pada Skenario II seluruhnya dapat dicapai tepat waktu (Tabel 5 dan Tabel 6), maka pada tahun 2014 diproyeksi-

Tabel 10. Proyeksi Ketersediaan Daging Sapi Nasional Berdasarkan atas Skenario II

\begin{tabular}{rrrrr}
\hline Tahun & $\begin{array}{r}\text { Total Produksi } \\
\text { Daging Sapi } \\
\text { Nasional }\end{array}$ & $\begin{array}{r}\text { Total Kebutuhan } \\
\text { Daging Sapi } \\
\text { Nasional }\end{array}$ & $\begin{array}{r}\text { Ketersediaan } \\
\text { Daging Sapi } \\
\text { Nasional }\end{array}$ & $\begin{array}{r}\text { Persentase Impor Daging } \\
\text { Sapi terhadap Kebutuhan } \\
\text { Daging Sapi Nasional }\end{array}$ \\
\cline { 2 - 5 } (Ribu Ton) & (Ribu Ton) & (Ribu Ton) & $\mathbf{( \% )}$ \\
\hline 2008 & 226,46 & 336,15 & $-109,68$ & 32,63 \\
2009 & 229,55 & 349,60 & $-120,05$ & 34,34 \\
2010 & 232,48 & 361,00 & $-128,52$ & 35,60 \\
2011 & 218,46 & 375,00 & $-156,54$ & 41,74 \\
2012 & 244,60 & 389,29 & $-144,70$ & 37,17 \\
2013 & 303,19 & 403,89 & $-100,70$ & 24,93 \\
2014 & 358,38 & 423,69 & $-65,31$ & 15,41 \\
2015 & 538,72 & 438,96 & 99,76 & 0 \\
2016 & 577,03 & 454,56 & 122,47 & 0 \\
2017 & 589,24 & 473,02 & 116,22 & 0 \\
\hline
\end{tabular}

Keterangan: Hasil simulasi model dinamis atas Skenario II 
Tabel 11. Proyeksi Populasi Sapi dan Total Pemotongan Sapi Nasional Berdasarkan atas Skenario II

\begin{tabular}{cccccc}
\hline Tahun & $\begin{array}{c}\text { Populasi } \\
\text { Sapi Lokal }\end{array}$ & $\begin{array}{c}\text { Populasi } \\
\text { Sapi Perah }\end{array}$ & $\begin{array}{c}\text { Total Populasi } \\
\text { Sapi Nasional }\end{array}$ & $\begin{array}{c}\text { Total } \\
\text { Pemotongan } \\
\text { Sapi Nasional }\end{array}$ & $\begin{array}{c}\text { Pertumbuhan } \\
\text { Populasi Sapi } \\
\text { Nasional }\end{array}$ \\
\cline { 2 - 6 } & (Juta Ekor) & (Ekor) & (Juta Ekor) & (Juta Ekor) & $\mathbf{( \% ) ~}$ \\
\hline 2008 & 11,23 & 457577 & 11,69 & 0,999300 & 3,17 \\
2009 & 11,53 & 531882 & 12,06 & 1,024000 & 5,06 \\
2010 & 12,05 & 614123 & 12,67 & 1,047000 & 6,39 \\
2011 & 12,78 & 704299 & 13,48 & 0,938294 & 10,83 \\
2012 & 13,91 & 766984 & 14,67 & 0,818868 & 12,55 \\
2013 & 15,41 & 842360 & 16,25 & 0,794265 & 14,22 \\
2014 & 17,36 & 939030 & 18,29 & 0,795692 & 12,16 \\
2015 & 19,85 & 1043000 & 20,89 & 1,522000 & 12,25 \\
2016 & 22,26 & 1167000 & 23,43 & 1,530000 & \\
2017 & 24,99 & 1312000 & 26,30 & 1,379000 & \\
\hline
\end{tabular}

Keterangan: Hasil simulasi model dinamis atas Skenario II

kan Indonesia masih harus mengimpor daging sapi (sapi bakalan) sebesar 15,41 persen dari total kebutuhan konsumsi masyarakat. Capaian ini tidak terlalu jauh dengan target yang diharapkan pemerintah, dimana diharapkan tahun 2014 target impor dalam bentuk daging dan sapi bakalan mencapai 10 persen. Pada simulasi tahun 2015 sampai 2017, tidak terjadi impor daging sapi (persentase impor 0 persen), sehingga kebutuhan daging terpenuhi dari produksi dalam negeri, seperti tergambar tahun 2015 sebesar 99,76 ribu ton dan meningkat sampai 116,22 ribu ton pada tahun 2017.

Dari hasil simulasi Skenario II, juga menunjukkan bahwa sejalan dengan keberhasilan program pengurangan pemotongan sapi lokal betina produktif (Tabel 5) yang dikombinasikan dengan program kawin silang dengan IB (Tabel 6), dalam jangka pendek (hingga tahun 2013) akan menyebabkan total sapi yang dipotong akan berkurang (Tabel 11). Hal ini akan menyebabkan persentase daging sapi yang harus diimpor untuk memenuhi kebutuhan konsumsi masyarakat Indonesia juga akan membesar hingga tahun 2013 (Tabel 10). Namun dalam jangka panjang keberhasilan kedua program tersebut akan berpengaruh signifikan pada upaya peningkatan populasi sapi lokal Indonesia, yang tampak jelas dengan semakin besarnya laju pertumbuhan populasi sapi nasional. (secara lengkap tercantum pada Tabel 11).
Secara umum hasil proyeksi Skenario II "apabila target program pengurangan pemotongan sapi lokal betina produktif dapat diimplementasikan tepat waktu (Tabel 5) dan target program kawin silang sapi lokal dengan IB juga dapat diimplementasikan tepat waktu (Tabel 6)" memperlihatkan peningkatan pertumbuhan populasi sapi nasional, yang pada skenario I dibawah 10 persen (Tabel 9), sedangkan pada skenario II ini dapat mencapai 14,22 persen pada Tahun 2015 (Tabel 11).

\section{Hasil Simulasi Model Dinamis Berdasarkan Skenario III}

Berdasarkan simulasi model dinamis atas Skenario III, berikut ini diuraikan hasil proyeksi ketersediaan daging sapi nasional di masa mendatang (Tabel 12). Apabila "target program pengurangan pemotongan sapi lokal betina produktif (Tabel 5) dan target program kawin silang sapi lokal dengan IB (Tabel 6) dapat diimplementasikan tepat waktu, dan pada saat yang sama terjadi peningkatan konsumsi daging sapi per kapita masyarakat Indonesia (seperti pada Tabel 7)", maka program swasembada daging sapi pada tahun 2014 tidak dapat dicapai. Diproyeksikan pada tahun 2014 persentase impor daging sapi Indonesia terhadap total kebutuhan konsumsi daging sapi masyarakat Indonesia masih cukup tinggi, yakni 33,48 persen. Pada tahun 2015 dan 2016 diproyeksikan terjadi penurunan impor daging sapi (7,56 dan 8,09 persen), namun dalam jang- 
Tabel 12. Proyeksi Ketersediaan Daging Sapi Nasional Berdasarkan atas Skenario III

\begin{tabular}{|c|c|c|c|c|}
\hline Tahun & $\begin{array}{r}\text { Total Produksi } \\
\text { Daging Sapi } \\
\text { Nasional }\end{array}$ & $\begin{array}{r}\text { Total Kebutuhan } \\
\text { Daging Sapi } \\
\text { Nasional }\end{array}$ & $\begin{array}{r}\text { Ketersediaan } \\
\text { Daging Sapi } \\
\text { Nasional }\end{array}$ & $\begin{array}{r}\text { Persentase Impor } \\
\text { Daging Sapi terhadap } \\
\text { Kebutuhan Daging } \\
\text { Sapi Nasional }\end{array}$ \\
\hline & (Ribu Ton) & (Ribu Ton) & (Ribu Ton) & $(\%)$ \\
\hline 2008 & 226,46 & 336,15 & $-109,68$ & 32,63 \\
\hline 2009 & 229,55 & 349,60 & $-120,05$ & 34,34 \\
\hline 2010 & 232,48 & 361,00 & $-128,52$ & 35,60 \\
\hline 2011 & 218,46 & 412,74 & $-194,27$ & 47,07 \\
\hline 2012 & 244,60 & 453,78 & $-209,18$ & 46,10 \\
\hline 2013 & 303,19 & 495,79 & $-192,60$ & 38,85 \\
\hline 2014 & 358,38 & 538,80 & $-180,41$ & 33,48 \\
\hline 2015 & 538,72 & 582,81 & $-44,08$ & 7,56 \\
\hline 2016 & 577,03 & 627,84 & $-50,82$ & 8,09 \\
\hline 2017 & 589,24 & 673,93 & $-84,68$ & 12,57 \\
\hline
\end{tabular}

Keterangan: Hasil simulasi model dinamis atas Skenario III

ka panjang menunjukkan impor akan cenderung semakin tinggi.

Dari hasil simulasi model dinamis atas Skenario III (Tabel 12) dapat disimpulkan, apabila terjadi peningkatan kebutuhan konsumsi daging sapi (seperti pada Tabel 7), maka sasaran program swasembada daging sapi pada tahun 2014 belum dapat dicapai dengan hanya mengandalkan indikator kebijakan aksi dengan target seperti pada Tabel 5 dan Tabel 6 saja, namun diperlukan kebijakan inovatif lainnya untuk mendukung program swasembada daging sapi yang telah ada.

\section{SIMPULAN}

Hasil penelitian ini menunjukkan bahwa, perta$m a$, model ketersediaan daging sapi nasional yang dikembangkan dengan pendekatan sistem dinamis dapat dikatakan mampu merepresentasikan 'dunia nyata'. Uji validitas model yang dilakukan menunjukkan bahwa model dinamis yang tersusun telah memiliki akurasi yang tinggi, dengan rata-rata absolut persentase kesalahan dibandingkan aktual sebesar 5,8 persen (untuk variabel total produksi daging sapi nasional) dan 7,28 persen (untuk variabel total kebutuhan konsumsi daging sapi nasional). Kedua, simulasi yang dilakukan terhadap model dinamis menunjukkan bahwa bila pemerintah menginginkan swasembada daging nasional tercapai tahun 2014, maka sasaran program tersebut tidak dapat dicapai dengan penyelenggaraan program peternakan bersifat bussiness as usual (Skenario I). Ketiga, swasembada daging sapi nasional diproyeksikan dapat dicapai pada Tahun 2015, apabila dilakukan intervensi kebijakan berupa: (a) pengurangan pemotongan sapi lokal betina produktif secara bertahap dengan jadwal dan target seperti pada Tabel 5; (b) meningkatkan secara bertahap program kawin silang sapi lokal dengan inseminasi buatan yang pada akhirnya akan meningkatkan berat per ekor dan calf crop sapi lokal dengan jadwal dan target seperti pada Tabel 6 (Skenario II). Namun kedua intervensi kebijakan tersebut masih belum mampu mencapai sasaran swasembada daging sapi nasional pada Tahun 2014 apabila kebutuhan konsumsi daging sapi masyarakat Indonesia juga turut meningkat seperti pada Tabel 7 (Skenario III). Melihat hasil simulasi ketiga skenario kebijakan tersebut tampak bahwa target dan jadwal kebijakan pada Skenario II sudah cukup baik, namun perlu juga diantisipasi apabila terjadi kenaikan kebutuhan konsumsi daging sapi masyakarat Indonesia, maka harus ada kebijakan inovatif lain untuk meningkatkan target pencapaian populasi sapi nasional dalam waktu lebih cepat. 


\section{DAFTAR PUSTAKA}

Ditjennak. 2010a. Pedoman Umum Program Swasembada Daging Sapi 2014. Jakarta: Direktorat Jenderal Peternakan Kementerian Pertanian.

Ditjennak. 2010b. Blue Print Program Swasembada Daging Sapi 2014. Jakarta: Direktorat Jenderal Peternakan, Kementan RI.

Ditjennak. 2010c. Pedoman Teknis Kegiatan Operasional PSDS 2014. Jakarta: Direktorat Jenderal Peternakan, Kementan RI.

Ditjennak. 2010d. Peta Wilayah Sumber Bibit Sapi Potong Lokal di Indonesia. Jakarta: Direktorat Jenderal Peternakan, Kementan RI.

Ditjennak. 2010. Statistik Peternakan 2010. Jakarta: Direktorat Jenderal Peternakan Kementerian Pertanian RI.

Ditjennak. 2009. Statistik Peternakan 2009. Jakarta: Direktorat Jenderal Peternakan Departemen Pertanian.

Dwiyanto, K. 2008. Pemanfaatan Sumber Daya Lokal dan Inovasi Teknologi dalam Mendukung Pengembangan Sapi Potong di Indonesia. Pengembangan Inovasi Pertanian. I(3), 2008: 173-188.

Ensminger, M.E; J.E. Oldfield; W.W. Heinemann. 1990. Feeds and Nutrion. Second Edition. California: The Ensminger Publishing Company.

Forrester, Jay W. 1968. Principles of Systems, 2nd Ed. Waltham: Pegasus Communications.
Forrester, Jay W. 1998. Designing the Future, at Universidad de Sevilla, Sevilla Spain. December 15, 1998.

Ilham, N. 2006. Analisis Sosial Ekonomi dan Strategi Pencapaian Swasembada Daging 2010. Analisis Kebijakan Pertanian. Vol. 4 No. 2, Juni 2006: 131-145.

Jumlah Penduduk Indonesia Tahun 2000, http://bps.go.id/, di-download pada Tanggal 5 Januari 2010.

May, Cheryl. 1981. Cattle Management. Virginia: A Prentice-Hall Company.

Sterman, J.D. 2000. Business Dynamics: Systems Thinking and Modelling for a Complex World. Boston: McGrawHill.

Subagyo, I. 2009. Potret Komoditas Daging Sapi. Economic Review. No. 217, September 2009.

Suryana. 2009. Pengembangan Usaha Ternak Sapi Potong Berorientasi Agribisnis dengan Pola Kemitraan. Jurnal Litbang Pertanian. 28(1), 2009.

Talib, C. 2001. Pengembangan Sistem Perbibitan Sapi Potong Nasional. Wartazoa, 11(1): 10-19.

Ventana Systems Inc. 2007. Vensim, DSS, Professional, PLE Plus, PLE with Causal Tracing Reality Check and SyntheSim, User's Guide Version 5. USA: Vantana System, Inc.

Yusdja, Y. dan N. Ilham. 2004. Tinjauan Kebijakan Pengembangan Agribisnis Sapi Potong. Jurnal Analisis Kebijakan Pertanian, 2(2): 167-182. 


\section{LAMPIRAN}

Lampiran. Formulasi Matematis, Units (Satuan), dan Keterangan Setiap Variabel di Dalam Model Dinamis Sistem Ketersediaan Daging Sapi Nasional (dipaparkan secara Alphabetis).

(1) Anak Sapi Betina Lokal= INTEG (Penambahan Anak Betina SL-Penambahan Betina Dewasa SL,2.79937e+006). Units: Ekor. Jumlah sapi lokal betina berumur 0-2 tahun di Indonesia.

(2) Anak Sapi Perah=Stok Sapi Perah Betina Dewasa*Calf Crop. Units: Ekor/Tahun. Jumlah anak sapi perah yang dilahirkan oleh total sapi perah betina dewasa.

(3) Anak Sapi Perah Betina= INTEG (Penambahan Anak Betina SP-Penambahan Betina Dewasa SP,125102). Units: Ekor. Jumlah sapi perah betina berumur 0-2 tahun di indonesia.

(4) "Anak-Sapi Lokal"=Sapi Betina Dewasa Lokal*Calf Crop. Units: Ekor/Tahun. Jumlah anak sapi lokal yang dilahirkan oleh total sapi betina dewasa lokal.

(5) Berat Sapi Bakalan=400. Units: Kg/Ekor. Rata-rata berat per ekor sapi bakalan yang sudah siap ke pemotongan.

(6) BeratSL Betina $=300$. Units: $\mathrm{Kg} /$ Ekor. Rata-rata berat per ekor sapi betina dewasa lokal tahun 2008.

(7) BeratSL Jantan3=200. Units: Kg/Ekor. Rata-rata berat per ekor sapi jantan lokal umur 3 tahun.

(8) BeratSL Jantan4=300. Units: Kg/Ekor. Rata-rata berat per ekor sapi jantan lokal umur 4 tahun.

(9) BeratSL Pejantan=350. Units: Kg/Ekor. Rata-rata berat per ekor sapi pejantan lokal umur 9 tahun.

(10) BeratSP Betina=350. Units: $\mathrm{Kg} /$ Ekor. Rata-rata berat per ekor sapi perah betina afkir Indonesia tahun 2008.

(11) BeratSP Jantan3=250. Units: $\mathrm{Kg} /$ Ekor. Rata-rata berat per ekor sapi perah jantan umur 3 tahun.

(12) BeratSP Jantan4=350. Units: Kg/Ekor. Rata-rata berat per ekor sapi perah jantan umur 4 tahun.

(13) Calf Crop=0.55. Units: $1 /$ Tahun. Rata-rata persentase anak sapi yang dihasilkan oleh total sapi betina dewasa.

(14) Daging Sapi Tercecer=Produksi Daging SL dan SP*Fraksi Daging Sapi Tercecer. Units: $\mathrm{Kg}$ /Tahun. Jumlah daging sapi yang tercecer atau rusah, sehingga tidak dapat dimakan.

(15) Defisit Daging Sapi Nasional=IF THEN ELSE(Ketersediaan Daging Sapi Nasional<0, ABS(Ketersediaan Daging Sapi Nasional),0). Units: Kg/Tahun. Jumlah kebutuhan daging sapi yang tidak dapat dipenuhi oleh produksi daging sapi nasional, sehingga harus diimpor.

(16) FINAL TIME $=12$. Units: Tahun. The final time for the simulation.

(17) Fraksi Daging=0.4125. Units: Dmnl. Rata-rata persentasi daging per ekor sapi.

(18) Fraksi Daging Sapi Tercecer=0.0595. Units: Dmnl. Rata-rata daging sapi yang tercecer per tahun.

(19) Fraksi Kematian Anak=0.1. Units: Dmnl. Rata-rata persentase kematian anak sapi lokal per tahun.

(20) Fraksi Konsumsi Daging Sapi([(0,0)-(12,10)],(0,1.38),(1,1.42),(2,1.45),(3,1.49),(4,1.53),(5,1.57), $(6,1.63),(7,1.67),(8,1.71),(9,1.76),(10,1.8),(11,1.84),(12,1.89))$. Units: $\mathrm{Kg}^{*} 1 /$ (Jiwa*Tahun). Ratarata konsumsi daging sapi per kapita per tahun penduduk Indonesia.

(21) Fraksi Pemotongan Betina Produktif=0.05. Units: 1/Tahun. Besar persentase sapi lokal betina produktif yang dipotong.

(22) Fraksi Pertumbuhan Penduduk Indonesia=0.01264. Units: $1 /$ Tahun. Rata-rata pertumbuhan penduduk Indonesia.

(23) INITIAL TIME $=0$. Units: Tahun. The initial time for the simulation.

(24) Jumlah Penduduk Indonesia= INTEG (Laju Pertumbuhan Penduduk Indonesia, 2.27128e+008). Units: Jiwa. Total jumlah penduduk Indonesia. 
(25) Kebutuhan Impor Sapi Bakalan=INTEGER(Defisit Daging Sapi Nasional/(Berat Sapi Bakalan*Fraksi Daging)). Units: Ekor/Tahun. Merupakan jumlah kebutuhan impor sapi bakalan yang setara dengan kebutuhan untuk menutup defisit daging sapi nasional.

(26) Ketersediaan Daging Sapi Nasional=Total Produksi Daging Sapi Nasional-Total Kebutuhan Daging Sapi Nasional. Units: Kg/Tahun. Menunjukkan surplus (positif) atau defisit (negatif) daging sapi nasional.

(27) Konsumsi Daging Sapi per Kapita=Fraksi Konsumsi Daging Sapi(Time). Units: (Kg/Jiwa)*1/ Tahun. Rata-rata jumlah daging sapi yang dikonsumsi oleh penduduk Indonesia per kapita per tahun.

(28) Laju Pertumbuhan Penduduk Indonesia=Jumlah Penduduk Indonesia*Fraksi Pertumbuhan Penduduk Indonesia. Units: Jiwa/Tahun. Penambahan jumlah penduduk Indonesia per tahun.

(29) Pemotongan Sapi Lokal=INTEGER(PemotonganSL Betina Afkir+PemotonganSL Pejantan+ PemotonganSL Betina Produktif). Units: Ekor/Tahun. Jumlah sapi yang dipotong, yang berasal dari peternakan sapi lokal Indonesia.

(30) Pemotongan Sapi Perah=INTEGER(PemotonganSP Betina Afkir+PemotonganSP Jantan4). Units: Ekor/Tahun. Jumlah sapi yang dipotong yang berasal dari peternakan sapi perah.

(31) PemotonganSL Betina Afkir=DELAY FIXED(Penambahan Betina Dewasa SL, Waktu Produktif, 674217). Units: Ekor/Tahun. Jumlah sapi lokal betina produktif yang dipotong pada umur 9 tahun.

(32) PemotonganSL Betina Produktif=Sapi Betina Dewasa Lokal*Fraksi Pemotongan Betina Produktif. Units: Ekor/Tahun. Banyaknya sapi lokal betina produktif yang dipotong pada tahun berjalan.

(33) PemotonganSL Jantan3=DELAY FIXED((Penambahan Anak Jantan SL*0.8), Waktu Jantan3, 989343). Units: Ekor/Tahun. Jumlah sapi lokal jantan yang dipotong pada umur 3 tahun.

(34) PemotonganSL Jantan4=DELAY FIXED((Penambahan Anak Jantan SL*0.1), Waktu Jantan4, 92751). Units: Ekor/Tahun. Jumlah sapi lokal jantan yang dipotong pada umur 4 tahun.

(35) PemotonganSL Pejantan=DELAY FIXED((Penambahan Anak Jantan SL*0.1), Waktu Pejantan, 41223). Units: Ekor/Tahun. Banyaknya sapi jantan lokal yang dipotong pada umur 9 tahun.

(36) PemotonganSP Betina Afkir=DELAY FIXED(Penambahan Betina Dewasa SP, Waktu Laktasi, 46520). Units: Ekor/Tahun. Jumlah sapi perah betina produktif yang dipotong pada umur 8 tahun.

(37) PemotonganSP Jantan3=DELAY FIXED((Penambahan Anak Jantan SP*0.9), Waktu Jantan3, 16006). Units: Ekor/Tahun. Jumlah sapi perah jantan yang dipotong pada umur 3 tahun.

(38) PemotonganSP Jantan4=DELAY FIXED((Penambahan Anak Jantan SP*0.1), Waktu Jantan4,1334). Units: Ekor/Tahun. Jumlah sapi perah jantan yang dipotong pada umur 4 tahun.

(39) Penambahan Anak Betina SL=("Anak-Sapi Lokal"*Rasio Jenis Kelamin)-("Anak-Sapi Lokal"*Rasio Jenis Kelamin*Fraksi Kematian Anak). Units: Ekor/Tahun. Penambahan anak betina sapi lokal pada tahun berjalan.

(40) Penambahan Anak Betina SP=(Anak Sapi Perah*Rasio Jenis Kelamin)-(Anak Sapi Perah*Rasio Jenis Kelamin*Fraksi Kematian Anak). Units: Ekor/Tahun. Penambahan anak betina sapi perah pada tahun berjalan.

(41) Penambahan Anak Jantan SL=("Anak-Sapi Lokal"*Rasio Jenis Kelamin)-("Anak-Sapi Lokal"*Rasio Jenis Kelamin*Fraksi Kematian Anak). Units: Ekor/Tahun. Penambahan anak jantan sapi lokal pada tahun berjalan.

(42) Penambahan Anak Jantan SP=(Anak Sapi Perah*Rasio Jenis Kelamin)-(Anak Sapi Perah*Rasio Jenis Kelamin*Fraksi Kematian Anak). Units: Ekor/Tahun. Penambahan anak sapi perah jantan pada tahun berjalan.

(43) Penambahan Betina Dewasa SL=DELAY FIXED(Penambahan Anak Betina SL, Waktu Pendewasaan, 1.39969e+006). Units: Ekor/Tahun. Penambahan sapi betina dewasa lokal pada 
tahun berjalan.

(44) Penambahan Betina Dewasa SP=DELAY FIXED(Penambahan Anak Betina SP, Waktu Pendewasaan, 62551). Units: Ekor/Tahun. Penambahan sapi perah betina dewasa pada tahun berjalan.

(45) Persentase Impor terhadap Kebutuhan Daging Sapi=Defisit Daging Sapi Nasional/Total Kebutuhan Daging Sapi Nasional ${ }^{*} 100$. Units: Dmnl. Besarnya persentase defisit daging sapi nasional terhadap total kebutuhan daging sapi nasional.

(46) Produksi Daging Sapi Lokal=(PemotonganSL Betina Afkir*BeratSL Betina+ PemotonganSL Betina Produktif*BeratSL Betina+PemotonganSL Jantan3*BeratSL Jantan3+PemotonganSL Jantan4*BeratSL Jantan4+PemotonganSL Pejantan*BeratSL Pejantan)*Fraksi Daging. Units: $\mathrm{Kg} /$ Tahun. Produksi daging sapi nasional yang berasal dari peternakan sapi lokal.

(47) Produksi Daging Sapi Perah=(PemotonganSP Betina Afkir*BeratSP Betina+ PemotonganSP Jantan3*BeratSP Jantan3+PemotonganSP Jantan4*BeratSP Jantan4)* Fraksi Daging. Units: $\mathrm{Kg} /$ Tahun. Produksi daging sapi nasional yang berasal dari peternakan sapi perah.

(48) Produksi Daging SL dan SP=Produksi Daging Sapi Lokal+Produksi Daging Sapi Perah. Units: $\mathrm{Kg} /$ Tahun. Porduksi daging sapi dari peternakan sapi lokal dan sapi perah.

(49) Rasio Jenis Kelamin=0.5. Units: Dmnl. Perbadingan jenis kelamin anak sapi, yakni 50\% jantan dan $50 \%$ betina.

(50) Sapi Betina Dewasa Lokal=INTEG (Penambahan Betina Dewasa SL-PemotonganSL Betina Afkir-PemotonganSL Betina Produktif,4.71952e+006). Units: Ekor. Jumlah sapi lokal betina berumur $>2-9$ tahun di Indonesia pada tahun berjalan.

(51) Sapi Jantan Lokal=INTEG (Penambahan Anak Jantan SL-PemotonganSL Jantan3-PemotonganSL Jantan4-PemotonganSL Pejantan,3.71004e+006). Units: Ekor. Jumlah sapi jantan lokal yang berumur 0-9 tahun di Indonesia pada tahun berjalan.

(52) Sapi Perah Jantan= INTEG (Penambahan Anak Jantan SP-PemotonganSP Jantan3-PemotonganSP Jantan4,53353). Units: Ekor. Jumlah sapi perah jantan umur 0-4 tahun di Indonesia pada tahun berjalan.

(53) SAVEPER = TIME STEP. Units: Tahun [0,?]. The frequency with which output is stored.

(54) Stok Sapi Perah Betina Dewasa= INTEG (Penambahan Betina Dewasa SP-PemotonganSP Betina Afkir,279122). Units: Ekor. Jumlah sapi perah betina berumur $>2-8$ tahun di Indonesia pada tahun berjalan.

(55) Surplus Daging Sapi Nasional=IF THEN ELSE(Ketersediaan Daging Sapi Nasional $>0$, Ketersediaan Daging Sapi Nasional, 0 ). Units: Kg/Tahun. Jumlah kelebihan produksi daging sapi nasional dari kebutuhan konsumsi nasional.

(56) TIME STEP $=1$. Units: Tahun [0,?]. The time step for the simulation.

(57) Total Kebutuhan Daging Sapi Nasional=Jumlah Penduduk Indonesia*Konsumsi Daging Sapi per Kapita. Units: Kg/Tahun. Total kebutuhan daging sapi untuk konsumsi penduduk Indonesia.

(58) Total Pemotongan Sapi=INTEGER(Pemotongan Sapi Lokal+Pemotongan Sapi Perah). Units: Ekor/Tahun. Jumlah sapi Indonesia yang dipotong (tidak termasuk sapi impor bakalan dan daging sapi).

(59) Total Populasi Sapi Indonesia=INTEGER(Total Populasi Sapi Lokal Indonesia+Total Populasi Sapi Perah Indonesia). Units: Ekor. Total populasi sapi Indonesia.

(60) Total Populasi Sapi Lokal Indonesia=INTEGER(Anak Sapi Betina Lokal+Sapi Jantan Lokal+Sapi Betina Dewasa Lokal). Units: Ekor. Total populasi sapi lokal Indonesia.

(61) Total Populasi Sapi Perah Indonesia=INTEGER(Stok Sapi Perah Betina Dewasa+Anak Sapi Perah Betina+Sapi Perah Jantan). Units: Ekor. Total populasi sapi perah Indonesia.

(62) Total Produksi Daging Sapi Nasional=Produksi Daging SL dan SP-Daging Sapi Tercecer. Units: $\mathrm{Kg} /$ Tahun. Total produksi daging sapi nasional yang dapat dikonsumsi penduduk Indonesia. 
(63) Waktu Jantan3=3. Units: Tahun. Waktu untuk pemeliharaan sapi jantan dari lahir hingga siap ke pemotongan umur 3 tahun.

(64) Waktu Jantan4=4. Units: Tahun. Waktu untuk pemeliharaan sapi jantan dari lahir hingga siap ke pemotongan umur 4 tahun.

(65) Waktu Laktasi=6. Units: Tahun. Waktu Laktasi adalah rata-rata periode waktu sapi-perah betina dewasa untuk laktasi.

(66) Waktu Pejantan=9. Units: Tahun. Waktu untuk pemeliharaan sapi pejantan lokal dari lahir hingga ke pemotongan pada umur 9 tahun.

(67) Waktu Pendewasaan=2. Units: Tahun. Lama waktu sapi betina dari lahir hingga siap bunting.

(68) Waktu Produktif=7. Units: Tahun. Lama waktu sapi betina dewasa lokal memproduksi anak sapi (masa produktif). 